\title{
The Genome Sequence of Five Genotypes of Fusarium oxysporum f. sp. vasinfectum: A Resource for Studies on Fusarium Wilt of Cotton
}

Seungyeon Seo, Ambika Pokhrel, and Jeffrey J. Coleman ${ }^{\dagger}$

Department of Entomology and Plant Pathology, Auburn University, Auburn, AL 36849, U.S.A.

\begin{abstract}
Fusarium oxysporumf. sp. vasinfectum is an important plant pathogen responsible for vascular wilt disease on cotton. Members of this group are known to carry supernumerary chromosomes that encode virulence factors. We sequenced the genomes of five $F$. oxysporum f. sp. vasinfectum isolates, including the genome of a representative of the highly virulent genotype race 4 , at a high coverage to assemble reference-quality genomes. These genomes provide a necessary resource for comparative genomic analyses to identify genes or genome features that are involved in pathogenicity on cotton and may ultimately be used to identify improved management strategies.
\end{abstract}

\section{Genome Announcement}

Members of the Fusarium oxysporum species complex (FOSC) are an economically important group of fungal pathogens, causing vascular wilt diseases in a broad range of plant species (Michielse and Rep 2009). Previous experimental and genomic analyses of members of the FOSC have revealed that these isolates carry supernumerary chromosomes that harbor host-specific virulence traits (Coleman et al. 2011; Ma et al. 2010; van Dam et al. 2017; Williams et al. 2016). Importantly, these chromosomes have been experimentally shown to be able to be laterally transferred to other isolates of the FOSC, expanding host range (Ma et al. 2010; Vlaardingerbroek et al. 2016; van Dam et al. 2017). $F$. oxysporum f. sp. vasinfectum is an agriculturally important pathogen on cotton (Gossypium spp.), causing Fusarium wilt in all cotton-growing areas worldwide (Davis et al. 2006). F. oxysporum f. sp. vasinfectum may exist in a disease complex with nematodes, resulting in increased disease severity, where infected plants can display symptoms of stunting, wilting, chlorosis, necrosis of the vascular tissue and leaves, and, ultimately, plant death (Davis et al. 2006). F. oxysporum f. sp. vasinfectum has been divided into several different genotypes, classified by DNA sequence analysis and pathogenicity assays (Cianchetta et al. 2015; Davis et al. 2006; Skovgaard et al. 2001). Isolates of the race 4 genotype are the most destructive, able to cause disease in the absence of nematodes, and has been a significant problem in California the past 20 years and has since been isolated in Texas (Halpern et al. 2018; Kim et al. 2005). Other emerging genotypes have resulted in significant crop losses in different cotton cultivars (Bell et al. 2019). These isolates are able to persist in infected soils for several years (Smith and Snyder 1975) and, therefore, the most practical measure for managing the

\section{${ }^{\dagger}$ Corresponding author: J. J. Coleman; jjcoleman@ auburn.edu}

The author(s) declare no conflict of interest.

Accepted for publication 6 October 2019.

\section{Funding}

This research was supported by Cotton Incorporated, the Alabama Agricultural Experiment Station, and United States Department of Agriculture National Institute of Food and Agriculture Hatch funding.

Keywords

genomics, metabolomics, proteomics

() 2020 The American Phytopathological Society 
disease is breeding for increased resistance. Understanding of the evolution of virulence of these pathogens for cotton could aid in an effective breeding strategy for cotton cultivars with increased resistance. Here, we report the genome assemblies of five different genotypes of $F$. oxysporum f. sp. vasinfectum isolates: races 1 and 4, MDS-12, LA108, and LA127/140.

Five isolates were collected from infected cotton presenting with symptoms indicative of Fusarium wilt and a pure culture was grown on potato dextrose agar plates. DNA was extracted following a cetyltrimethylammonium bromide and Qiagen genomic-tip procedure (Kohler et al. 2015). F. oxysporum f. sp. vasinfectum isolates TF1 (race 1), 89-1A (race 4), LA1E (MDS-12), LA3B (LA108), and 14-004 (LA 127/140) were sequenced to 163x, 178x, $184 \times, 238 \times$, and 179x coverage, respectively, using the PacBio RS II System at the Duke Center for Genomic and Computational Biology. De novo assemblies of raw reads were performed using Canu v1.4 with the default settings, except the expected size was set for the race 4 genome at $65 \mathrm{Mb}$, the MDS-12 genome at $55 \mathrm{Mb}$, and the remaining F. oxysporum f. sp. vasinfectum genomes at $50 \mathrm{Mb}$ (Koren et al. 2017). The quality of the assemblies was validated via QUAST v 4.6.3 and BUSCO v 3.0.1 programs using the dikarya ortholog gene lineage dataset and the -sp parameter, fusarium_graminearum (Gurevich et al. 2013; Simão et al. 2015). The draft genomes of isolates TF1, LA3B, and 14-004 were approximately $50 \mathrm{Mb}$ in size and the LA1E isolate had a slightly larger genome size of $53 \mathrm{Mb}$ (Table 1). The race 4 isolate had distinctive genome characteristics when compared with the other F. oxysporum f. sp. vasinfectum isolates; in particular, a larger genome size, $63 \mathrm{Mb}$, which was distributed in 94 scaffolds (Table 1). Despite the differences, the percent GC content was almost the same at approximately $47 \%$ for all the genomes. The BUSCO results indicated that the assembled genomes were more than $98 \%$ complete.

The five genome assemblies were annotated using Funannotate $v 1.5 .0$ pipeline (Palmer 2017), with raw transcriptomic data sets generated by gossypol-treated race 4 F. oxysporum f. sp. vasinfectum $89-1 \mathrm{~A}$ isolate samples at two different time points. Total RNA was extracted as previously described (Coleman et al. 2009), and the quality and integrity of the RNA was verified by Bioanalyzer before sequencing by Illumina with 50-bp, paired-end sequencing at the Hudson Alpha Institute of Biotechnology. Prior to Funannotate, the repeated regions in the assembled genomes were softmasked by RepeatMasker. The masked genome was used for ab initio gene model prediction training by Augustus and GeneMark-ES gene prediction tools, and functional annotation was processed to protein-coding gene models. Overall, the race 4 genome encoded a larger number of genes $(n=20,222)$ as well as higher proportion of repetitive sequences $(18.44 \%)$ compared with the other sequenced $F$. oxysporumf. sp. vasinfectum genomes, where there were approximately 18,000 protein-coding genes, and less than $10 \%$ repetitive regions in their genomes. The genome data has been deposited in the National Center for Biotechnology Information GenBank database, BioProject number PRJNA552091, with the accession numbers and BioSamples in Table 1.

Table 1. Genome assembly statistics of five Fusarium oxysporum f. sp. vasinfectum isolates

\begin{tabular}{|c|c|c|c|c|c|}
\hline \multirow[b]{2}{*}{ Statistics } & \multicolumn{5}{|c|}{ Genotype } \\
\hline & Race 1 & Race 4 & MDS-12 & LA108 & LA127/140 \\
\hline Isolate & TF1 & $89-1 A$ & LA1E & LA3B & $14-004$ \\
\hline Coverage & $163 x$ & $178 x$ & $184 x$ & $238 x$ & $179 x$ \\
\hline Number of scaffolds & 17 & 94 & 26 & 17 & 18 \\
\hline Genome size (bp) & $50,043,501$ & $63,323,888$ & $53,532,301$ & $50,437,808$ & $51,686,574$ \\
\hline GC content $(\%)$ & 47.40 & 47.65 & 47.44 & 47.48 & 47.35 \\
\hline $\mathrm{N}_{50}(\mathrm{bp})$ & $4,223,171$ & $3,569,865$ & $3,332,013$ & $4,733,764$ & $4,700,795$ \\
\hline $\mathrm{L}_{50}$ & 5 & 7 & 7 & 5 & 5 \\
\hline Longest contig (bp) & $6,421,299$ & $6,635,028$ & $5,403,155$ & $6,382,753$ & $6,464,399$ \\
\hline Contigs $>25 \mathrm{~kb}$ & 17 & 86 & 25 & 17 & 17 \\
\hline BUSCO completeness & $98.80 \%$ & $98.70 \%$ & $98.20 \%$ & $98.80 \%$ & $98.50 \%$ \\
\hline Number of predicted genes & 17,975 & 20,222 & 19,054 & 18,132 & 18,195 \\
\hline Repetitive sequence (bp) & $3,125,885$ & $11,679,362$ & $4,607,798$ & $3,585,278$ & $3,914,995$ \\
\hline Repetitive sequence & $6.25 \%$ & $18.44 \%$ & $8.61 \%$ & $7.11 \%$ & $7.57 \%$ \\
\hline $\mathrm{NCBI}$ accession & VINL00000000 & VINP00000000 & VINN00000000 & VINM00000000 & VINO00000000 \\
\hline BioSample & SAMN12175309 & SAMN12175305 & SAMN12175307 & SAMN12175308 & SAMN12175306 \\
\hline
\end{tabular}




\section{Acknowledgments}

We thank R. M. Davis and H. Doan at the University of California, Davis for providing the

89-1A, LA1E, and LA3B isolates of $F$. oxysporum f. sp. vasinfectum sequenced in this study.

\section{Literature Cited}

Bell, A. A., Gu, A., Olvey, J., Wagner, T. A., Tashpulatov, J. J., Prom, S., Quintana, J., Nichols, R. L., and Liu, J. 2019. Detection and characterization of Fusarium oxysporum f. sp. vasinfectum VCG0114 (race 4) isolates of diverse geographic origins. Plant Dis. 103:1998-2009.

Cianchetta, A. N., Allen, T. W., Hutmacher, R. B., Kemerait, R. C., Kirkpatrick, T. L., Lawrence, G. W., Lawrence, K. S., Mueller, J. D., Nichols, R. L., Olsen, M. W., Overstreet, C., Woodward, J. E., Davis, R. M., Allen, T. W., and Mueller, D. 2015. Survey of Fusarium oxysporum f. sp. vasinfectum in the United States. J. Cotton Sci. 19:328-336.

Coleman, J. J., Rounsley, S. D., Rodriguez-Carres, M., Kuo, A., Wasmann, C. C., Grimwood, J., Schmutz, J., Taga, M., White, G. J., Zhou, S., Schwartz, D. C., Freitag, M., Ma, L. J., Danchin, E. G. J., Henrissat, B., Coutinho, P. M., Nelson, D. R., Straney, D., Napoli, C. A., Barker, B. M., Gribskov, M., Rep, M., Kroken, S., Molnár, I., Rensing, C., Kennell, J. C., Zamora, J., Farman, M. L., Selker, E. U., Salamov, A., Shapiro, H., Pangilinan, J., Lindquist, E., Lamers, C., Grigoriev, I. V., Geiser, D. M., Covert, S. F., Temporini, E., and Vanetten, H. D. 2009. The genome of Nectria haematococca: Contribution of supernumerary chromosomes to gene expansion. PLoS Genet. 5:e1000618.

Coleman, J. J., Wasmann, C. C., Usami, T., White, G. J., Temporini, E. D., McCluskey, K., and VanEtten, H. D. 2011. Characterization of the gene encoding pisatin demethylase (FoPDA1) in Fusarium oxysporum. Mol. Plant-Microbe Interact. 24:1482-1491.

Davis, R. M., Colyer, P. D., Rothrock, C. S., and Kochman, J. K. 2006. Fusarium witt of cotton: Population diversity and implications for management. Plant Dis. 90:692-703.

Gurevich, A., Saveliev, V., Vyahhi, N., and Tesler, G. 2013. QUAST: Quality assessment tool for genome assemblies. Bioinformatics 29:1072-1075.

Halpern, H. C., Bell, A. A., Wagner, T. A., Liu, J., Nichols, R. L., Olvey, J., Woodward, J. E., Sanogo, S., Jones, C. A., Chan, C. T., and Brewer, M. T. 2018. First report of Fusarium wilt of cotton caused by Fusarium oxysporum $\mathrm{f}$. $\mathrm{sp}$. vasinfectum race 4 in Texas, U.S.A. Plant Dis. 102:446.

Kim, Y., Hutmacher, R. B., and Davis, R. M. 2005. Characterization of California isolates of Fusarium oxysporum f. sp. vasinfectum. Plant Dis. 89:366-372.

Kohler, A., Kuo, A., Nagy, L. G., Morin, E., Barry, K. W., Buscot, F., Canbäck, B., Choi, C., Cichocki, N., Clum, A., Colpaert, J., Copeland, A., Costa, M. D., Doré, J., Floudas, D., Gay, G., Girlanda, M., Henrissat, B., Herrmann, S., Hess, J., Högberg, N., Johansson, T., Khouja, H.-R., LaButti, K., Lahrmann, U., Levasseur, A., Lindquist, E. A., Lipzen, A., Marmeisse, R., Martino, E., Murat, C., Ngan, C. Y., Nehls, U., Plett, J. M., Pringle, A., Ohm, R. A., Perotto, S., Peter, M., Riley, R., Rineau, F., Ruytinx, J., Salamov, A., Shah, F., Sun, H., Tarkka, M., Tritt, A., Veneault-Fourrey, C., Zuccaro, A., Mycorrhizal Genomics Initiative Consortium, Tunlid, A., Grigoriev, I. V., Hibbett, D. S., and Martin, F. 2015. Convergent losses of decay mechanisms and rapid turnover of symbiosis genes in mycorrhizal mutualists. Nat. Genet. 47:410-415.
Koren, S., Walenz, B. P., Berlin, K., Miller, J. R., Bergman, N. H., and Phillippy, A. M. 2017. Canu: Scalable and accurate long-read assembly via adaptive $k$-mer weighting and repeat separation. Genome Res. 27:722-736.

Ma, L.-J., van der Does, H. C., Borkovich, K. A., Coleman, J. J., Daboussi, M.-J., Di Pietro, A., Dufresne, M., Freitag, M., Grabherr, M., Henrissat, B., Houterman, P. M., Kang, S., Shim, W.-B., Woloshuk, C., Xie, X., Xu, J.-R., Antoniw, J., Baker, S. E., Bluhm, B. H., Breakspear, A., Brown, D. W., Butchko, R. A. E., Chapman, S., Coulson, R., Coutinho, P. M., Danchin, E. G. J., Diener, A., Gale, L. R., Gardiner, D. M., Goff, S., Hammond-Kosack, K. E., Hilburn, K., Hua-Van, A., Jonkers, W., Kazan, K., Kodira, C. D., Koehrsen, M., Kumar, L., Lee, Y.-H., Li, L., Manners, J. M., Miranda-Saavedra, D., Mukherjee, M., Park, G., Park, J., Park, S.-Y., Proctor, R. H., Regev, A., Ruiz-Roldan, M. C., Sain, D., Sakthikumar, S., Sykes, S., Schwartz, D. C., Turgeon, B. G., Wapinski, I., Yoder, O., Young, S., Zeng, Q., Zhou, S., Galagan, J., Cuomo, C. A., Kistler, H. C., and Rep, M. 2010. Comparative genomics reveals mobile pathogenicity chromosomes in Fusarium. Nature 464:367-373.

Michielse, C. B., and Rep, M. 2009. Pathogen profile update: Fusarium oxysporum. Mol. Plant Pathol. 10:311-324.

Palmer, J. 2017. Funannotate: Eukaryotic genome annotation pipeline. https:// funannotate. readthedocs.io/en/latest/

Simão, F. A., Waterhouse, R. M., loannidis, P., Kriventseva, E. V., and Zdobnov, E. M. 2015. BUSCO: Assessing genome assembly and annotation completeness with single-copy orthologs. Bioinformatics 31:3210-3212.

Skovgaard, K., Nirenberg, H. I., O'Donnell, K., and Rosendahl, S. 2001. Evolution of Fusarium oxysporum f. sp. vasinfectum races inferred from multigene genealogies. Phytopathology 91:1231-1237.

Smith, S. N., and Snyder, W. C. 1975. Persistence of Fusarium oxysporum f. sp. vasinfectum in fields in the absence of cotton. Phytopathology 65:190-196.

van Dam, P., Fokkens, L., Ayukawa, Y., van der Gragt, M., Ter Horst, A., Brankovics, B., Houterman, P. M., Arie, T., and Rep, M. 2017. A mobile pathogenicity chromosome in Fusarium oxysporum for infection of multiple cucurbit species. Sci. Rep. 7:9042.

Vlaardingerbroek, I., Beerens, B., Rose, L., Fokkens, L., Cornelissen, B. J. C., and Rep, M. 2016. Exchange of core chromosomes and horizontal transfer of lineage-specific chromosomes in Fusarium oxysporum. Environ. Microbiol. 18: 3702-3713.

Williams, A. H., Sharma, M., Thatcher, L. F., Azam, S., Hane, J. K., Sperschneider, J., Kidd, B. N., Anderson, J. P., Ghosh, R., Garg, G., Lichtenzveig, J., Kistler, H. C., Shea, T., Young, S., Buck, S. A. G., Kamphuis, L. G., Saxena, R., Pande, S., Ma, L. J., Varshney, R. K., and Singh, K. B. 2016. Comparative genomics and prediction of conditionally dispensable sequences in legume-infecting Fusarium oxysporum formae speciales facilitates identification of candidate effectors. BMC Genomics 17:191. 